Adorno, Hegel, and Dialectic

Abstract

This article explores critical theory's relations to German idealism by clarifying how Adorno's thought relates to Hegel's. Adorno's apparently mixed responses to Hegel centre on the dialectic and actually form a coherent whole. In his Logic, Hegel outlines the dialectical process by which categories - fundamental forms of thought and reality - necessarily follow one another in three stages: abstraction, dialectic proper, and the speculative (famously simplified as 'thesis, antithesis, synthesis'). Adorno's allegiance to Hegel's dialectic emerges when he traces the dialectical process whereby enlightenment reverts to myth and human domination over nature reverts into our domination by nature. However, Adorno criticises Hegel's dialectic as the ultimate form of 'identity thinking', subsuming unique, material objects under universal concepts by using dialectical reason to expand those concepts to cover objects utterly. These two responses cohere because Adorno shares Hegel's view that dialectical contradictions require reconciliation, but differs from Hegel on the nature of reconciliation. For Hegel, reconciliation unites differences into a whole; for Adorno, reconciled differences co-exist as differences. Finally, against Habermas who holds that Adorno cannot consistently criticize the enlightenment practice of critique, I show that Adorno can do so consistently because of how he reshapes Hegelian dialectic.

Keywords:

Adorno, critical theory, dialectic, enlightenment, Habermas, Hegel, nature 


\section{Adorno, Hegel, and Dialectic}

In this article I aim to shed light on the relations between German idealism and critical theory by providing a fresh interpretation of how Theodor Adorno's thought relates to that of G. W. F. Hegel. ${ }^{1}$ The title of Adorno's best-known work, the Dialectic of Enlightenment, already bespeaks a substantial debt to Hegel, the philosopher of dialectic. Adorno and Horkheimer diagnose how the world-historical drive towards 'enlightenment' - increased use of reason to gain knowledge of nature and apply that knowledge for human benefit - repeatedly transforms into its opposites, myth and barbarism. This diagnosis of enlightenment's failings reflects a broader approach: tracing how some phenomenon, concept, or institution turns of its own momentum into its contrary, thereby undergoing a 'dialectic'. This approach derives from Hegel. In his Logic Hegel maintains that any concept or structure that is 'posited' as independently subsisting necessarily undergoes a transformation into its opposite: this is the movement of dialectic. In his Phenomenology of Spirit Hegel describes the eighteenth-century intellectual movement of the Enlightenment as being subject to just such a dialectic whereby it transformed into its supposed opposite, 'faith' (Glaube) (PhG 329-49/400-24; and see Bernstein, 'Negative Dialectic as Fate', 22-23). ${ }^{2}$ Thus, in arguing that enlightenment reverts into myth, Adorno is informed by

\footnotetext{
${ }^{1}$ I thank the referees and editors for their suggestions for improving the earlier draft of this paper.

${ }^{2}$ For frequently quoted works I use these abbreviations. DA: Adorno, Dialectic of Enlightenment/Dialektik der Aufklärung; EL: Hegel, The Encyclopaedia Logic/Enzyklopädie I; ND: Adorno, Negative Dialectics/Negative Dialektik; PhG: Hegel, Phenomenology of Spirit/Phänomenologie des Geistes; WL: Hegel, Science of
} 
Hegel. Admittedly, Adorno regards enlightenment as a world-historical process of which the eighteenth-century movement was only an advanced stage. Yet that suggests that Adorno is committed to viewing the whole course of history in dialectical terms, again following Hegel.

It appears that the form of critical theory championed by Adorno in the Dialectic of Enlightenment renews Hegel's dialectic to address the political and cultural upheavals of the twentieth century. Yet in Negative Dialectics, Adorno criticises Hegel for being the arch-proponent of 'identity-thinking', whose metaphysical and ethical failing is to take thought and being to be identical. Hegel can only defend that metaphysical position by effecting a thorough-going subsumption of objects, in all their material reality and unique individuality, under universal concepts. According to Adorno, Hegel does this by developing his expanded form of reason dialectical reason - which permits us to trace again and again how objects escape our concepts and then enlarge those concepts to subsume objects once more, ultimately covering everything in a complete system of thought. ${ }^{3}$ Hegel's categories may be Logic/Wissenschaft der Logik. For Hegel's works I give either paragraph number (when available) followed after a comma by English pagination, or English pagination followed after a slash by German. Translations are occasionally amended without special notice.

${ }^{3}$ Adorno's complaint that Hegel annexes what is other into thought into the self-same thinking subject has affinities with many later twentieth-century French critiques of Hegel - e.g. Derrida, Glas; Irigaray, '...the eternal irony of the community...' in Speculum. Judith Butler defends Hegel against these kinds of critique by arguing that when the subject expands through the encounter with what it is other to it, that subject becomes other than it initially was (see Butler, Subjects of Desire). Presumably 
mobile and expansive, but - Adorno objects - that is because Hegel aims to capture all that exists in the net of thought. Thus, for Adorno, it is through dialectic that Hegel purports to establish that thought and being are identical (as we shall see further in Section 3). After all, then, Adorno's critical theory seems defined against Hegelian dialectic, condemned as manifesting the world-historical tendency for subjects thinking beings whose thought is structured by concepts - to dominate objects unique material existents - by categorizing and controlling them.

Adorno's relation to Hegel is thus ambivalent: Adorno's critique of enlightenment appears both Hegelian and anti-Hegelian, to rest on both acceptance and rejection of Hegelian dialectic. ${ }^{4}$ This ambivalence centres on the dialectic: it is dialectic that Adorno seems both to accept - in critiquing enlightenment - and to reject - in critiquing Hegel's expansion of thought to cover objects comprehensively. ${ }^{5}$

Adorno would reply that this becoming-other remains merely expansion for purpose of dominating the other.

${ }^{4}$ Alternative accounts of Adorno's ambivalent relation to Hegel are given by Baumann, ‘Adorno, Hegel'; Bernstein, 'Negative Dialectic as Fate'; Finlayson, 'Normativity and Metaphysics'; Macdonald, “"The Wounder will Heal”; O’Connor, ‘Adorno's Reconception'.

${ }^{5}$ Of course, Adorno engages critically with other dimensions of Hegel's thought too, notably his view of world history as a necessary progression and his concept of spirit as a unity in which individual subjects participate. But those engagements can be seen as part and parcel of Adorno's response to the dialectic - after all, Adorno criticises Hegel on these matters in his book Negative Dialectic, thus in the overarching context of re-thinking dialectic. What Adorno above all rejects in Hegel's philosophy of history is his belief that the course of world history is progressive, against which 
In fact, I will argue, Adorno's response to the dialectic is coherent. ${ }^{6}$ Adorno regards Hegel's dialectic as having positive and negative aspects, and he endeavours to extricate the positive aspects and forge his own philosophical approach from them. Adorno's relation to Hegel bears more broadly on the project of critical theory. Jürgen Habermas argues that Adorno cannot coherently criticize enlightenment and conceptual thinking for dominating objects while continuing the enlightenment practice of critical thinking in advancing this very critique. Pace Habermas, I will argue that Adorno can coherently criticize enlightenment critique by

Adorno insists that every historical progression so far has engendered a concomitant regression - that is, that enlightenment has always been subject to dialectic. Thus dialectic remains central to Adorno's response to Hegel on history. Regarding the concept of spirit, Adorno fears that it subordinates individuals to the whole at an intellectual level, prefiguring the totalitarian social trends of the twentieth century (see, e.g., ND 307-8/302-3). This fear stems from Adorno's broader concern to rescue what is individual and unique from coverage by universal concepts, a concern that in turn reflects his critique of Hegel's use of dialectic to subordinate the individual to the universal. So, again, Adorno's critical engagement with Hegel on spirit ties back to the central issue of dialectic.

${ }^{6}$ Adorno might say that given an incoherent social world it is better to reflect those incoherences in thought than mask them with a falsely coherent system, as per his slogan 'Wrong life cannot be lived rightly' (Es gibt kein richtiges Leben im falschen) (Minima Moralia, 39). Yet to censure the modern social world for its incoherence - as wrong or false - Adorno must accept coherence as an ideal, which makes it an apposite standard for assessing his work. 
virtue of the way that he reshapes Hegelian dialectic. Thus Adorno's form of critical theory is not subject to the incoherence of which Habermas accuses it.

\section{Hegel: Dialectic as Ontology}

To reconstruct Adorno's response to Hegel's dialectic we first need to consider how Hegel understands dialectic. He defines it in his Encyclopaedia Logic (1817, revised 1827,1830 ) when explaining that his project in the Logic is to trace the complete set of basic categories or thought-determinations (Gedankenbestimmungen). Hegel understands these categories to organize both our experience and the world external to our minds. The categories are not only mental rules or ordering principles but also organizing principles that obtain in the world mind-independently and thus structure nature, history, and ultimately the totality of all that is. ${ }^{7}$ By calling the categories 'essentialities' (Wesenheiten) Hegel indicates that they comprise the essential structure of things themselves (WL 28/1: 17). He also claims that thought, qua objective, is the inwardness of the world .... The meaning of thinking and of its determinations is more precisely expressed by the ancients when they say that nous governs the world, or by our own saying that there is reason in the world. (EL §24 A/56)

\footnotetext{
${ }^{7}$ In taking the categories to organise the world as well as our thought, I am opposing the influential 'non-metaphysical' line of recent Hegel interpretation, championed inter alia by Pippin, Hegel's Idealism, and Pinkard, Hegel's Dialectic. With others who defend metaphysical interpretations (e.g. Beiser, German Idealism; Wartenberg, 'Hegel's Idealism'), I believe that the non-metaphysical readings diverge unduly from the often metaphysical letter of Hegel's texts, such as the passages that I quote here.
} 
Elsewhere, too, he reiterates that the categories, or the 'universality of things is not something subjective and belonging to us; it is, rather, the truth, objectivity, and actual being of the things themselves. It resembles the Platonic ideas ... which exist in individual things as their substantial kinds' (Gattungen) (Hegel, Philosophy of Nature, §246A, 1: 200). This overarching metaphysical commitment informs the detail of the categories that Hegel traces in his Logic. When he theorises causality, for instance, he treats it not only as a category by which we must order our experience but also as a principle bringing all mind-independent things into causal relations. ${ }^{8}$

Dialectic governs the sequence of categories as Hegel traces it. As is well known, for Hegel, all categories follow one another according to a three-stage process of abstraction, dialectic, and the speculative (EL §79, 125) - famously caricatured as thesis-antithesis-synthesis. ${ }^{9}$ The second moment is dialectical in the proper or narrow sense: it is the moment of opposition, in which speech or reasoning (legein) is pulled between (dia-) two directions. The presence of this dialectical moment in the whole

\footnotetext{
${ }^{8}$ Talk of a 'mind-independent' world simplifies, because for Hegel the world necessarily develops into and so cannot exist independently of mind. But, for Hegel, the world is not mind-dependent in the way that it is for Kant, for whom the (empirical) world receives its organizing structure from mind. For Hegel, the world has its own organizing structure, not imparted by mind; the tensions within that structure propel the world to develop, through the realm of nature, into mind. The world necessarily becomes mind, but it does not necessarily derive its structure from mind. Although simplified, then, talk of 'mind-independence' picks out this important difference between Hegel and Kant.

${ }^{9}$ The caricature goes back to Marx and his teacher Hans Chalybäus; see Gustav E. Mueller, 'The Hegel Legend', 304.
} 
three-stage process of categorial development makes that process dialectical in the broader sense, that of being driven along by oppositions or tensions and their resolutions. By 'Hegel's dialectic', I will (as most interpreters do) mean the dialectical process in this broad sense unless context points to its strict meaning.

To elaborate on Hegel's dialectic in this broad sense, I now want to read Hegel's schematic characterisation of this three-stage process alongside the first three-stage process that he traces: the development being-nothingness-becoming, which opens both his Encyclopaedia Logic and his 1812-16 Science of Logic. Because this reading is preparatory for reconstructing Adorno's response to the dialectic, I will purposely avoid making any innovative interpretive claims about Hegel, beyond the fact that I construe the dialectic as obtaining in mind-independent reality as well as thought. This aside, I will confine myself to distinguishing the three stages of the dialectic clearly, because their distinction is crucial to how Adorno refashions dialectic.

Schematically, then, in abstraction or 'understanding' (Verstand) some category obtains - in our thinking and in the objective world - in 'abstraction' from whatever processes have generated it. Exemplifying this first stage, Hegel begins his logic with being (Sein). Being is the simplest and most inescapable category, necessarily presupposed in any thought or existence at all: anything that is must participate in being (EL §86, 136-39).

The second, strictly dialectical stage arises as the given category proves unstable and turns into its antithesis. Being is entirely indeterminate and featureless; it is, in fact, nothingness, Nichts (EL §87, 139; WL 82/1: 83). When thinking of being, we find that the category under which we are thinking is actually that of nothingness; everywhere in the world that the organizing principle of being obtains, actually what 
is structuring entities is an empty, indeterminate nothingness. Yet nothingness, too, contradicts itself, turning back into being: both alike are featureless, indeterminate and empty, so nothingness is no different from being after all (WL 82/1: 83).

From this apparent stalemate Hegel extracts a positive implication: being and nothingness are distinct, because it is from opposite starting-points and in opposite directions that they prove the same. Nothingness turns into being, whereas being turns into nothingness: 'the former is coming-to-be [Entstehen] and the latter is ceasing-tobe [Vergehen]' (WL 106/1: 112). Having thereby ascertained that being and nothingness are distinct (unterschieden), Hegel infers that they are also interdependent (inseparable, untrennbar), because each obtains only inasmuch as the other constantly turns into it (83/1: 83).

This combination of distinctness and interdependence makes both categories into aspects of a third, overarching structure. This structure is becoming (Werden), which consists of nothing more than the continual movement of being into nothingness and back (EL §88, 141). This provides resolution (Auflösung) because an overarching structure has emerged of which the first and second moments are reduced to partial elements (WL 105/1: 112). Whereas being and nothingness were selfcontradictory, the whole - becoming - to which they now belong is not: becoming does not immediately collapse back into either being or nothingness because it overarches and incorporates them both. Thus, we have reached (an instance of) the third, 'speculative' stage, which reconciles the first two categories with one another. Now, for Hegel, it is vital that each resolving structure be nothing more than the combination into a unity of the two moments preceding it. This reflects a commitment to parsimony that organises all his transitions between categories. For Hegel, some category $\mathrm{C}$ counts as the necessary solution to the conflict between $\mathrm{A}$ 
and $\mathrm{B}$ if $\mathrm{C}$ corrects $\mathrm{A}$ and $\mathrm{B}$ 's limitations while differing from $\mathrm{A}$ and $\mathrm{B}$ in content less than any other category (Forster, Hegel's Idea, 186). That is, a category arises necessarily just in case it resolves the preceding conflict(s) as parsimoniously as possible. But why does Hegel so value parsimony?

Each resolution that has arisen is only temporary, for problems arise in each third category. Precisely because each third category (e.g. becoming) unites its two predecessors, it differs from them as they were before they were combined into a unity. Just as reconciling, each reconciling structure differs from the elements that it reconciles. In this respect being and nothingness (for instance) remain partially outside the reconciling structure, and so their antagonism is not fully reconciled by it after all. This is why the solution to a conflict should differ from that conflict only so far as is required to resolve it and no more. Because even that difference may be enough to engender further problems, the ideal is to reduce the difference to a vanishingly small degree - hence Hegel's commitment to parsimony.

The logical process continues, then, as each third category turns into its opposite: it was supposed completely to resolve the pre-existing opposition, but it has left that opposition partly unresolved. Thus the dialectical moment (in the strict sense) recurs: having first become established in its own right, 'abstractly' (e.g. as becoming), the new category has now contradicted itself, 'dialectically'. As Hegel puts it, becoming at first is merely the 'one-sided immediate unity of these moments, [that] is determinate being' (Dasein; WL 106/1: 113). That is, becoming is the unity and not also the difference of the moments, so that their difference falls outside becoming, such that it is not a complete unity after all. Another resolving category is required; that category in turn will, qua resolution, remain different from the conflicts that it resolves. And so on, through a whole chain of categories, until we reach the 
final category, the absolute idea - itself nothing more than the whole of all the preceding links in the chain.

For Hegel, this chain of categories obtains in the world as well as in thought: he regards dialectic as an ontological process unfolding everywhere, so that the world is fundamentally structured both by contradictions and the rational process of overcoming them. That process does not eradicate contradictions but retains and neutralises them. For instance, becoming does not outright annul the contradictions internal to being and nothingness; rather, becoming is constituted as the overarching structure that it is by retaining and using those contradictions (for becoming is the dual movement in which being and nothingness self-contradict and become one another). The upshot is that contradictions are built into every level of reality for Hegel, each nested within a higher level that arises from the rational impulse to overcome contradictions yet contains contradictions in turn.

Is dialectic a method? Following Marx, many theorists have so treated it - as a method applicable to thinking about various matters, such as class antagonisms (Marx, 'Postface', 102-3). Yet Hegel claims that his only 'method' is to abstain from using any special methods and simply to follow, and reproduce in his own words, thought's intrinsic movement. Knowledge, he says, 'demands surrender to the life of the object, ... confronting and expressing its inner necessity’ (PhG 32/52). This reflects Hegel's view that the world of objects is in itself structured by thought, which in turn might suggest that Hegel regards dialectic more as an ontological feature of the world than as a method. But how do we discern and describe reality's developmental processes? Everything develops dialectically for Hegel, including human knowledge: we learn by framing concepts, following out and solving their contradictions, forging new concepts, identifying their problems, and so on. Just when 
we think in this dialectical way, our thought comes to reproduce the dialectical structure of the world. So dialectic is not only a method, for Hegel, because dialectic also obtains ontologically - but, for that very reason, dialectical thinking is the right method for grasping reality, and thus dialectic is a method in part.

However, for Hegel, dialectical thinking is not just one possible method of inquiring amongst others. In thinking dialectically we simply follow the movement intrinsic to thought as it obtains in and outside the mind. We certainly do not apply the schema abstraction-dialectic-reconciliation, as a lifeless formula, to whatever subject-matter is at hand ( $\mathrm{PhG} 29 / 48$. Thus, attributing the schema thesis-antithesissynthesis to Hegel is a misleading caricature). Rather, when we immerse ourselves in our subject-matter and think its processes through, we find that the three-stage pattern recurs again and again, albeit under endless modifications and embedded in increasingly complex variations. We can then describe the pattern schematically - as Hegel does in the Encyclopaedia Logic - but the schema is the result of inquiry, not its presupposition (EL §83A, 133-4).

These views of Hegel's - that reality is constituted by dialectical processes which rational thinking can comprehensively capture - will be criticised by Adorno. But first let us consider his positive response to Hegel's dialectic.

\section{Dialectic of Enlightenment}

Adorno's positive response to Hegel guides his (and Horkheimer's) central contentions in the Dialectic of Enlightenment that 'myth is already enlightenment; and enlightenment reverts to mythology' (DA xvi/16). By 'enlightenment' (Aufklärung) Adorno means the world-historical process in which we have made ever-increasing use of conceptual understanding to gain knowledge about nature - both outer nature 
(our physical environment) and inner nature (our make-up as human beings) understanding applied with the aim of controlling nature to promote human wellbeing. The more this enlightenment project is pursued, the more it engenders a regression into enlightenment's opposite - myth, magical thinking and barbarism epitomised by the rise of anti-Semitism under the National Socialists. Why does this regression happen? To re-examine this, we first need to reconstruct Adorno's account of enlightenment, which he (and Horkheimer) present in a deliberately fragmentary manner.

Enlightenment is rooted in our desire to gain practical control over nature, including our own nature, for our own benefit: 'The enlightenment has always aimed at ... establishing humans as masters' (DA 3-4/20). Initially, human beings sought this control from magic and myth - which, then, were actually the earliest stages of enlightenment. On the magical worldview, all nature was pervaded by spiritual power, mana (15/31). Mana was held to interconnect all things such that we could control one thing by controlling another in magical practice: say, manipulating a person by stealing and acting on a lock of their hair. In the first mythic worldview that succeeded magic in history, mana became differentiated and personalised, different places regulated by 'local spirits and demons' (8/24). Next these local deities were amalgamated to constitute 'heaven and its hierarchy', such as the ancient Greek pantheon. In both mythic stages, human beings tried to influence the divinities through sacrifices and rituals and to predict their actions through oracles and divination (49-50/67-8). Thus both magic and myth were early efforts to know and control nature.

Enlightenment progressed as people came to think that magic and, in turn, myth offered mere false beliefs about nature, not real insight into nature's workings 
(DA 14/30). In the name of magic and myth's own motivations - to know and control nature - those belief-systems were rejected as false, 'animistic', 'ensouling' the world with (really non-existent) supernatural powers and agencies, imagined on the model of human life, thought or personality $(5 / 21,28 / 45)$. Condemning faith in gods for supernaturalism and anthropomorphism, humanity came instead to believe that universal forms or substances structure nature and permit it to be controlled advancing from theology to metaphysics (5-6/21-2). Finally, coming to regard those forms as another residue of myth, humanity replaced them with numbers, reducing nature to quantities of moving matter or energy or force - the transition to modern science (7/24). Thus humanity has criticised and rejected each belief-system in turn for being mythical, anthropomorphic and not conferring real, practically useful knowledge. Extricating ourselves from each belief-system in turn, we have tried again and again to know nature as it really, objectively, is - culminating in modern mathematical science with the unprecedented power over nature that it affords (DA 24-5/41-2).

The more we have tried to distance our thinking from myth, the more we have fallen back into myth and magic. This is the consequence of a repeated fall back from attempted control over nature into control by nature. That fall in turn happens because the entire enlightenment project has been fuelled by our impulse towards selfpreservation (Selbsterhaltung), towards securing our subsistence and well-being - a natural impulse. The very impulse to dominate nature is a natural impulse, a ramification of our natural impulse towards self-preservation. So, in trying to understand and control nature, we are actually submitting unreflectively to our own natural urges, letting them control us. 'Human history, the progressive mastery of 
nature, continues the unconsciousness of nature, devouring and being devoured' (ND $355 / 348-9)$.

Enlightenment reverts to myth because attempted human control over nature reverts to natural power over humanity. But what is the logical form of this dialectic of enlightenment? It shares the form of the dialectic that, for Hegel, afflicts being, which turns into nothingness just when it is posited in its own right. Likewise, it is precisely when enlightened thought tries to separate itself from myth, and when humanity thereby tries to separate itself from nature, that the dialectical moment occurs. When enlightened thought tries to posit itself in abstraction from myth, as something independent from and not contaminated by myth, just then this thought proves dependent on and mixed in with myth. We see this pattern in all the phases of enlightenment. For example, by adopting mythic worldviews, humankind aspired to gain real knowledge and control of nature; but precisely because humanity thought that its mythic belief-systems were free of magic, they overlooked the way that myth remained completely driven by human impulses and wishes, thus affording us only false beliefs pervaded by anthropomorphic fantasies and projections - just as magic did, into which myth had therefore relapsed. The same pattern has persisted right into techno-scientific modernity. Thus, there has been a repeated oscillation between the first and second stages of Hegel's dialectic - the moments of abstraction, in which enlightenment tries to posit itself separately from myth and magic, and that of dialectic proper, in which myth and magic reassert their inextricability from enlightenment.

It might be objected that rather than enlightenment and myth being related dialectically, their relation is chiasmatic, so that each continually turns into the other, the two lines of transformation traversing one another to form a cross. Such a view of 
the enlightenment-myth relation is set out in Adorno's 1932 essay 'The Idea of Natural History'. Here he maintains not only that history is already nature but also, reciprocally, that nature is already history ('Natural History', 117), contrary to any belief in some essential core of nature persisting unchanged across history. One way that nature is already history is that nature has always been subjected to human thinking and practical activity, and thus involved in historical processes of transformation (processes of domination, Adorno suggests here, that have brought about nature's destruction or ruination). So thorough-going is this involvement of history in nature that each natural object contains sedimented within it the history of humankind's effects upon it. History is already nature, on the other hand, in a way that Dialectic of Enlightenment will reprise more clearly than this early essay: namely that history is the history of our efforts to dominate nature, yet where those efforts are driven all along by our natural impulses.

In Dialectic of Enlightenment Adorno maintains the cross-wise structure intimated in the earlier essay insofar as he claims that myth is already enlightenment (DA xvi/16). Myth and magic, as we've seen, are intrinsically systems of practice and belief through which humankind has sought to understand and control nature. Even though we have progressively distanced ourselves from these systems, that is because they failed to deliver what they promised: mastery of nature. Underlying this way that myth is already enlightenment is, again, the way that nature already impels us to seek to control it. Nature itself, in the guise of our inner impulses towards selfpreservation, drives the project of securing human mastery over nature.

Yet enlightenment and myth, human history and nature, can be related chiasmatically and dialectically as well. As we have seen, the repeated reversion of enlightenment to myth exemplifies the movement in Hegel's dialectic whereby that 
which is posited abstractly undergoes a dialectical reversal into its opposite. It now transpires that the myth into which enlightenment reverts is not simply enlightenment's opposite after all, for myth already is enlightenment in nuce. This recalls the point in Hegel's being-nothingness-becoming dialectic when, being having proved entirely empty and so identical to nothingness, nothingness reciprocally proves identical to being because nothingness has no qualities other than those that already characterise being. Likewise, the very features that characterise myth - its provision of a primitive way of understanding and controlling nature - mark it as an early form of enlightenment. Myth and enlightenment pass reciprocally into one another, just as being and nothingness do.

Does the dialectic of enlightenment have any third, reconciling moment akin to Hegelian becoming? No reconciliation has yet occurred in history, but we can see in Adorno's work the suggestion of a pathway along which humanity might accomplish such reconciliation (Versöhnung) for the first time. This pathway is implied by Adorno's diagnosis of the dialectical relation between myth and enlightenment, a diagnosis that indicates an alternative possibility: 'Through the decision in which spirit acknowledges itself to be domination and retreats into nature, it abandons the claim to domination which directly enslaves it to nature' (DA 39-40/57). If spirit, i.e. human beings as enlightened thinkers, took this 'decision' (Bescheidung) to 'retreat into nature', they would be acknowledging that their thought depends on the natural impulses that fuel it. Adorno also calls this the 'remembrance of nature in the subject' (40/58). Remembering that it is all along naturally driven, thinking would also 'acknowledge itself to be domination', because the impulses fuelling it have been impulses towards domination. In that case, by acknowledging the dependency of our patterns of thinking and activity on our natural impulses, we would be aware of those 
impulses at work in and on us. We could then decide whether we wish to pursue these impulses or not, and if so in what ways. That is, our awareness of the ongoing force of our inner nature would open up the space in which we could exercise some freedom of choice with respect to that nature. Paradoxically, admitting our dependency on nature would enable us to realize, better than ever before, the enlightenment goal of winning freedom from natural impulses. Likewise in terms of knowledge, if we acknowledged that our thinking depends on nature, then we could reflect on how natural impulses are shaping our thought and potentially distorting it by leading us to view the world as we wish it to be rather than as it is. Again, admitting dependency on nature would allow us to attain greater objectivity than was possible when we sought to transcend nature. ${ }^{10}$

Adorno's anticipated form of reconciliation appears to have a Hegelian structure. The first term - enlightenment/reason - accepts its dependence on the second - natural impulse - and so, it seems, also succeeds in distinguishing itself from that second term. Analogously, Hegel maintains that being succeeds in becoming distinct from nothingness just in that being turns into nothingness along its particular direction - ceasing-to-be - and thus in that being is interdependent with nothingness, into which being continually passes. Interdependency makes distinctness possible. But for Hegel that interdependency makes being and nothingness joint aspects of one overarching structure, becoming. Adorno does not make the parallel claim that enlightenment and myth would be reconciled if they were united into an

\footnotetext{
${ }^{10}$ We might object to Adorno that if our thought is driven by nature to the extent that he claims, then surely what we need to acknowledge is that we cannot ever achieve either objectivity or the freedom to decide how to respond to our inner nature's promptings. But that is an issue for another paper.
} 
overarching whole. The reason is that, for Adorno, natural impulse does not depend on enlightened thought to the same level that enlightened thought depends on nature. Their dependency on one another is not symmetrical and equal as is that of being and nothingness for Hegel. We see the asymmetry in that enlightened thought is driven by natural impulse, and reverts into nature because nature was powering it all along, whereas natural impulse is already enlightenment in that all along nature drives the enlightenment endeavour. Nature is primary and generates enlightenment. Or, as Adorno puts it, the object has 'primacy' over thinking (Vorrang; ND 192/193). He explains this in his essay 'Subject and Object'. Any thinking, reasoning subject is a particular object - a body, brain, and set of impulses - but not all objects are reasoning subjects. Thought depends on objectivity for its very existence: 'concepts $\ldots$ are moments of the reality that requires their formation' (11/23). Mind originates in the 'real life process', Adorno adds; consciousness is 'a ramification of the energy of drives' (198/265, 199/262).

Adorno's belief in the dependency of thought on nature is complicated by his further view that all objects do have an intelligible structure: definite properties or 'forms' that we can identify under concepts. To this extent, he says that objects have a 'subjective' element: a way that they are adapted to our understanding and so evince a kind of dependency on reason: 'The general assurance that ... insights, cognitions are "merely subjective" ceases to convince as soon as subjectivity is grasped as the object's form', as it is by Hegel, he says ('Subject and Object', 504). We might think that Adorno cannot possibly be agreeing with Hegel here, since that would be tantamount to accepting Hegel's equation of thought and being. Indeed, Adorno continues by saying that Hegel wrongly reduces the object to its subjectively intelligible form. But Adorno thereafter insists that the object is not absolute either; 
rather, 'the object ... is also nothing without the subject. If the object lacked the subject as a moment of itself, its objectivity would become a nonsense' (509). Thus he does believe that that which is subjective is a moment or aspect of the object - a moment that makes the object something determinate (not nothing) that we can understand (rather than a non-sense).

Thus, up to a point, Adorno agrees with Hegel that objects have intelligible forms. But Adorno thinks that as well as having such forms objects always have further elements that defy understanding: the sheer fact of their existence; their materiality in its thick, opaque presence; and the ways that, over and above whatever universal properties objects embody, they are each unique. Whereas Hegel believes that those further features can be reduced to thought-categories, Adorno considers these features irreducible (see Section 3). As a result nature, and what Adorno always aligns with nature, the object, necessarily exceed the subject's thinking capacities. In sum, by virtue of their intelligible forms objects have a degree of subject-dependence - their primacy vis-à-vis the subject is dialectical, not absolute ('Subject and Object', 505) - but, in contrast, thinking subjects are object-dependent through and through. If subjects were not also objects they could never think at all, nor would they have any motivations for doing so or for their thinking to assume any determinate shape. So dependent on nature are thinking subjects that the only level of freedom from nature they can ever win comes from, and indeed consists in, their admitting this dependency.

Here Adorno's difference from Hegel begins to emerge. For Hegel, all that exists is structured through-and-through by thought-forms; for Adorno, objects are only partly so structured and their intelligible side never exhausts them. Consequently, for Adorno, mind and nature depend on one another but not 
reciprocally so; rather, nature and its material objectivity have primacy, so that we must acknowledge our dependency on nature to be reconciled with it. Adornian and Hegelian reconciliation thus differ. The difference is conveyed when Adorno states that reconciliation is "neither the undifferentiated unity of subject and object nor their hostile antithesis, but rather the communication of the different' ('Subject and Object', 499). Reconciliation, as he envisages it (with Hegel), involves neither fusion of nor antagonism between the first two moments of the dialectical process. But contra Hegel, Adornian reconciliation holds together differences - of object from concept, nature from subject, myth from enlightenment - letting them remain different, juxtaposed as such, without subsuming them under any unifying structure. Difference persists when nature is admitted to extend beyond, have priority to, and generate thought, non-reciprocally. The only unifying structure that Adornian reconciliation adds to the differences is the acceptance of their difference as difference, nothing more.

Still, Adorno's conception of reconciliation remains partly Hegelian: Adorno too seeks for subject and object to be brought together non-antagonistically. But, against Hegel, Adorno thinks that that non-antagonism requires the admission of an asymmetrical dependency of subject on object, an asymmetry that prevents these two elements from forming a unitary whole. Thus their difference subsists as difference. In this very respect, though, we might after all see Adornian reconciliation as being even more Hegelian than Hegelian reconciliation. For Hegel, a successful reconciliation must differ from the opposed terms that it reconciles as little as possible, otherwise that attempted solution will after all fall outside what it aims to reconcile, generating further dialectical developments. Yet a reconciliation that merely combines opposed terms in their difference, as Adornian reconciliation does, 
differs from those opposed terms more minimally than a Hegelian-style reconciliation which unites those terms under a third structure. Even when Adorno diverges from Hegel, then, there remains a Hegelian dimension to his divergence.

\section{Identity and Non-Identity Thinking}

Further reasons why Adorno diverges from Hegel on reconciliation emerge in Negative Dialectics of 1966, in which Adorno contends that the impulse to dominate the object is fundamental to Hegel's dialectical logic. This contention is part of the broader critique of 'identity-thinking' that Adorno elaborates in this work.

Identity thinking is conceptual, classificatory thinking, with which humanity has endeavoured across history to gain real knowledge about things. The connection between conceptualisation and the project of knowing the world is shown, for instance, by Aristotle's epistemology. For Aristotle, understanding is necessarily of universals grasped under concepts, not of particulars given to perception (Aristotle, Posterior Analytics, 42-43, 87b28-39). Yet universals only ever exist as instantiated in multiple particulars. Consequently, by knowing universals we do also know about particular things - but in respect of the universals that they embody as distinct from their sheer particularity.

For Adorno, the activity of conceptualising universals and classifying objects under them constitutes identity-thinking. Concepts each apply to many different things, all those that instantiate the universal that a given concept picks out (e.g., the concept book applies to all those things of the type that book picks out). Hence, with each concept we classify the things to which it applies as instances of the corresponding universal (conceiving something to be a book, I treat it as an instance of this type). Conceptual thinking specifies 'what something falls under, of which it is 
an example' (ND 149/152). When I conceive something as an instance of a kind, I treat it as 'identical' to all that kind's other instances, for they are all its instances, exactly alike in this status. In classifying something I therefore gain no insight into what is unique about this thing, what distinguishes this book from all the others. Thus in conceptualizing things I also 'identify' them with the universal kinds to which they belong, and I lack insight into any respects in which things go beyond this identity. Adorno does not consider identity-thinking wholly misguided. As we saw earlier, he accepts that things come under concepts by embodying intelligible forms. ${ }^{11}$ Yet identity thinking tells us not the whole truth about objects but only about their universal and intelligible side. Indeed, by giving us no way to appreciate or learn about the countervailing, unique side of things, identity thinking tends to disguise the very fact that things have that unique side. Identity thinking is partial, but it falsely presents itself as the whole. Above all, Adorno objects that identity thinking is inextricable from the world-historical project of controlling objects by conceptualizing them. This control is morally invidious domination (Beherrschung), in which we have forced other natural beings to deviate from their own intrinsic purposes and instead serve human purposes (Stone, 'Adorno and Disenchantment', 233-4). Since we too are natural, we have also dominated ourselves: ultimately, we

\footnotetext{
${ }^{11}$ Here Adorno diverges from Nietzsche, contrary to Habermas's claim that Adorno is very largely a Nietzscheian (Habermas, Philosophical Discourse, 121). Nietzsche maintains in his 1873 essay 'On Truth and Lying in an Non-Moral Sense' that all conceptualisation of things under universals is a fabrication enabling us to cope with a fundamentally chaotic world (see Nietzsche, Birth of Tragedy, 139-53). In contrast, for Adorno, classification enables practical mastery by giving knowledge of the intelligible forms that things really do embody.
} 
have all become dominated by the instrumental rationality embodied in large-scale, bureaucratic organisations. Identity-thinking is implicated in the moral problems of these world-historical developments.

One might object that this critique of identity-thinking cannot rightly apply to Hegel, for the whole point of his dialectic is to advance beyond identity-thinking or, in his parlance, beyond abstract understanding (Verstand). For Hegel, to employ understanding is to generalize across a range of particulars to form a concept of the universal features that they share (making Hegelian understanding very close to identity-thinking). Our concept of these universal features is 'abstract' in that it 'holds fast' to what the particulars share, in abstraction from (by 'omitting', weglassen) the respects in which the particulars each differ from one another (EL §163A1, 240; WL 602/2: 275). In contrast, a 'concrete universal' differentiates itself into the various ways in which the particulars are particular. Hegel describes as follows the transition from abstract to concrete universal, in thought and reality alike.

A universal can only exist by being instantiated in many particulars, always in a particular, distinctive way. Each thing's particular way of embodying the universal necessarily goes beyond what is contained in the universal as that which all things of the kind share, whatever their particular ways of embodying it. The universal hereby undergoes a dialectic: the universal can obtain only if it is accompanied by and generates its 'negation' - the many 'determinations of the concrete' (WL 602/2: 275). However, just in this respect, the universal can be realized only by being dispersed into a range of unique particulars, so that these after all do not negate the universal but rather are the conditions of its realization: 'it follows ... that the first negative, or the determination, is not a limitation for the universal which, on the contrary, maintains itself therein and is positively identical with itself' (602/2: 276). For Hegel, the 
universal is self-differentiating, existing only by being manifested or embodied in a plurality of ways. The new category crystallizing this resolution is individuality or singularity (Einzelheit): a thing's particular way of instantiating a universal (indeed, ultimately a whole set of universals, differentiated from one another) is what makes that thing the singular individual that it is. The singular individual holds together the universal and the particular within itself.

From Adorno's perspective, Hegel's dialectic universal-particular-singular does not challenge but defends identity-thinking, subsuming the particular under the universal with unprecedented thoroughness. For Hegel grasps that which is unique in things under the categories particularity and individuality - thereby classifying what is unique, assigning it its place in his ontology (ND 136/140). Particularity and individuality mark universal types that all things instantiate insofar as they have particular ways of embodying their (other) universal properties. So, just when things seemed to have particularities that escaped the universal, Hegel grasps those particularities as embodying further universals - particularity, individuality - which, woven into his sequence of all the categories, ensure that all that is embodies a universal. Adorno concludes that 'as soon as we reflect upon the single ... individual as an individual, in the form of a universal concept - as soon as we cease to mean only the present existence of this particular person [or thing] - we have already turned it into a universal' (Adorno, 'Subject and Object', 498). Treating the individual qua individual as an instance of the universal type individuality, we forget that things are always more than mere embodiments of universals, even of individuality - which (assuming that such a universal exists) each thing must still exemplify in a unique way, thereby going beyond even that universal and remaining inexhaustibly singular. 
For Adorno, Hegel's reduction of the particular to one more universal reveals the dominating character of Hegelian dialectic. Hegel rightly sees that there is always more to objects than the universals that they embody. But in response Hegel expands the range and kind of universals that ontology recognises (by adding particularity and individuality; by recasting the universal as concrete and self-differentiating), so as to recapture this resistant element in things. Dialectic is his tool for effecting this expansion. The particularity of things outreaches the (abstract) universal and threatens to dissipate it (dialectically); yet, since the universal cannot exist without suffering this dispersal, the dispersal is necessary for the universal, thus its means of selfrealization (resolution). By tracing this dialectic, Hegel rethinks the universal in an enlarged sense, as self-differentiating into the whole range of universals including those of singular individuality and particularity. As Hegel puts it, his result is that the universal has grown to remain unchanging even in what seemed to be its antithesis: 'The universal, even when it posits itself in a determination, remains therein what it is ... [and] continues itself through that process undisturbed and possesses the power of unchangeable, undying self-preservation [Selbsterhaltung]' (WL 602/2: 276).

In this light Adorno views Hegelian dialectic generally as a mechanism for expanding thought to cover objects. Each category encounters its limit; the paradigm of all such limits is the sheer uniqueness of things, which conceptual thought confronts as its antithesis. In response Hegelian thought grows, re-appropriating its antitheses by evolving into successive new categories that at last close up into a complete system, objects fully covered. This shows that what Adorno finds problematic in Hegel's dialectic is - as we saw earlier apropos of the Dialectic of Enlightenment - the way that Hegel conceives the dialectic's third, speculative moment. For Adorno, that third moment as Hegel conceives it is not genuinely 
conciliatory but represents merely the first moment of the dialectic expanding to dominate the second - an 'unrestrained expansion of the subject' (Hegel: Three Studies, 5).

Hegel would reply that no such restoration of the first term to power takes place here, but an achievement of interdependency between first and second terms. For Adorno, that reply has two problems. First, the dialectic's first moments (enlightenment; the concept; the subject) are not really reciprocally interdependent with the second ones (myth; the object; nature) but fundamentally depend on those second moments, a dependency that needs to be acknowledged for any true reconciliation to be possible. By instead affirming interdependency Hegel disguises this radical dependency of conceptual on objective elements, according the first, conceptual terms more power than they really have. Second, Hegel believes that in their interdependency the two elements are united into a whole. But for Adorno this whole, just as a single whole, is at a structural level a version of the first term restored: the one restored to unity out of division.

Is that last criticism fair? Perhaps not: after all, Hegel criticises each third moment (e.g. becoming as the unity of being and nothingness) where it excludes the difference between the elements that it unites; that exclusion propels further dialectical development. Thus Hegel appears to agree with Adorno that it is a problem for any third term to effect unity (and thus to be aligned with the first term against the second). However, for Hegel, this is a problem because it means that the reconciling moment is not sufficiently conciliatory: that moment does not yet include difference within it, so its unity fails to be complete because difference falls outside it. Complete unity therefore remains the goal of Hegelian dialectical development. Whereas for Hegel each third moment proves problematic because it is not unified enough, for 
Adorno Hegel's thirds are too unified, disguising the real asymmetry of concept and object (ND 158/160). One might respond that for Hegel, categories can only achieve complete unity by fully incorporating difference, so that ultimately the problem of imperfect resolutions is indeed (as for Adorno) that they are too unified and not sufficiently accommodating of difference. Yet, for Hegel, the reason why difference needs to be accommodated is so that genuine unity can at last be achieved, as the full incorporation of all differences. For Adorno, conversely, it is difference that we ought to liberate from unity at last.

Yet Adorno considerably tempers even this critique of Hegel. To see this, consider his notion of the non-identical. Adorno wishes to avoid treating this as a concept of what all things have in common such that they are identical neither to one another nor to the kinds to which they belong. But the non-identical aspect of things is not something that we sense rather than grasp under concepts. Informed by Hegel's critique of sense-certainty, Adorno insists that we have no immediate sensory access to anything: all perception is mediated (ND 186/187-8, 172/173), so thoroughly that we cannot even disentangle conceptual and perceptual contributions to experience. It seems that we can only access the non-identical aspect of things under the concept of the non-identical. We need this concept to enable us to recognize the non-identical yet, somehow, we are to avoid doing so in a classifying, subsumptive way.

Perhaps, then, the non-identical is a limit-concept, not giving us positive knowledge or classification of things but only indicating where conceptual knowledge runs up against its limit. The concept of the non-identical indicates that there is a side of things that our concepts cannot cover, about which we cannot know, just because this side is that in things of which all concepts fall short. The concept of the nonidentical does not constitute an attempt to bridge this gap, but merely conveys that the 
gap is there. In this connection Adorno speaks positively of 'Kant's block': Kant's limit-concept of things-in-themselves (e.g. ND 386/378). This concept marks that there must be things-in-themselves otherwise there would be nothing to appear to us under our forms of representation, but that we cannot positively know anything about these things-in-themselves because we only know them under these forms of representation.

Despite this enthusiasm for Kant's block, Adorno also endorses (what he takes to be) Hegel's rejoinder to Kant: that whenever we identify a limit to our knowledge, we already place ourselves beyond that limit just by identifying the limiting factor and so bringing it within our compass. Our supposed cognitive limits thus undergo a dialectic, turning into an absence of cognitive limits. This self-contradictory situation obliges us to move decisively beyond the limit by expanding our concepts to recover the object. Adorno follows Hegel here - surprisingly, since Hegel's move appears to typify the dominating character of his dialectic. Nevertheless, following Hegel, Adorno maintains that whenever I grasp an object as non-identical with the concept(s) under which I have approached it, I become compelled to revise my concept(s) so as to try again to know, to classify, the elusive object. He articulates this movement in terms of 'constellations'.

Suppose that I try to know the book in front of me under the concept book (for Adorno's points concern even the most mundane material objects). This tells me nothing about this particular book. So I generate further concepts: green-covered, paperback, dog-eared, annotated, etc. I try to grasp the object in its uniqueness by covering it with a range of concepts, where no two objects ever fall under quite the same range. (We open the concept onto the object by using a combination of numbers, not just one, Adorno writes; ND 163/166). Apparently, then, by amassing a 
range of concepts around an object we can know it. 'Constellations illuminate what is specific in the object, to which the classificatory procedure is indifferent' (ND 162/164). But how can a range of concepts afford us knowledge of what is specific to a thing? Surely such concepts only reveal the multiple universals that an object embodies, not the object's unique way of embodying them - unless we reduce the latter to the unique range of universals embodied, in which case we would again, with Hegel, have reduced the non-identical to the identical.

Strictly speaking, though, Adorno says only that constellations 'illuminate what is specific in the object' - where illumination is not necessarily full knowledge, and where what is illuminated is what is specific. What happens, for Adorno, in constructing a constellation is that we propose a succession of concepts each correcting something of what its predecessor(s) missed out (I improve on book by adding to it green-covered; on green-covered book - which still fails to differentiate this book from many others on the shelf - by adding paperback; and so on). But the series does not add up to complete knowledge of the object. The group of concepts only centre around (zentrieren um) the object, Adorno says - by implication forming a circle around it that, like planets orbiting the sun, never touch the object at their centre (ND 162/164). Even the total group of concepts cannot adequate to the object because its unique side lies beyond not only each single concept but also the whole group of concepts qua concepts. This transcendence of the object is what the limitconcept of the non-identical picks out.

Yet having marked that limit, we do not stop trying to know the object - contra Kant, Adorno says, who gave up on real knowledge too easily (ND 175/177). We keep adding to each constellation, enriching it, indefinitely. We keep pushing back the 'block', the limit: it returns, but we keep trying to move beyond it, even as it moves 
along with us. We become led into constructing new constellations around neighbouring objects with which our first object is entangled - 'knowledge of the object in its constellation is cognition of the process stored in the object' $(163 / 166)$. For example, trying to specify what is unique about the book before me, I start to distinguish it from other books on the shelf by assigning each of them its properties, and so on endlessly. ${ }^{12}$

Building up constellations is not just an endless, empty process: constellations do illuminate things. What they inform us about is the range of universals that an object embodies, thus about its intelligible, 'subject-dependent' side. This is only ever partial knowledge of the object, the unique side of which remains transcendent. But our acknowledgement of this motivates us to keep trying, and in so doing we increase our knowledge about the object's universal side, thereby gaining knowledge. Although that knowledge always remains partial, within that partiality our knowledge of the object in its temporal and spatial connections with other objects can keep growing. Acknowledging our limits thus motivates rather than stymies knowledgeacquisition.

This way that the object always outstrips the subject (epistemologically) is the correlate of the asymmetrical dependency of the subject on the object (ontologically). Because objects precede and constitute subjects, objects always outreach the subject, comprising a background of which any subject is only ever a limited, and cognitively

\footnotetext{
${ }^{12}$ Adorno's example is that we progress in knowing about capitalism not by defining it (as, say, 'a system of production for profit') but by building up a set of concepts capturing the elements that have coalesced historically to compose this system: free labour, the separation of households from workplaces, accounting, a rationalistic legal system, etc. (ND 166/168).
} 
limited, part. Thus Adorno rejects Hegel's view that we can exhaustively know objects under the entire system of concepts. Adorno's disagreement with Hegel here is consistent both with Adorno thinking dialectically - when he shows how each concept, in turn, proves limited - and even, to an extent, with Adorno thinking 'rationally' in the Hegelian sense of moving beyond any limit towards a greater whole (see O’Connor, ‘Adorno’s Reconception', 540). After all, Adorno agrees with Hegel that we always move beyond each of our limits in turn and do so by grouping concepts together, building constellations that become more and more interrelated and therefore yield greater knowledge of objects. Grow as it might, though, that knowledge only ever remains partial, continuing to be limited by the non-identical.

\section{The Coherence of Adorno's Critical Theory}

The viability of Adorno's critical theory is challenged by Habermas, whose challenge motivates his turn to 'second-generation' critical theory. Habermas objects that when Adorno criticises rational thought as a whole (as Adorno does: 'to think is to identify'; ND 5/17) as an instrument of the subject's domination over the object, Adorno invalidates the rational thought with which he makes this critique (Habermas, Philosophical Discourse, 119-20). Adorno's position undermines itself, Habermas concludes (127-9). To escape the same contradiction, Habermas founds his successor form of critical theory on the distinction between two forms of reason: communicative, intersubjective (or subject-subject) reason, oriented towards free agreement amongst rational agents; and subject-object reason, oriented to knowledge and practical control of objects (295-6). By wrongly equating the latter with reason as a whole, Habermas thinks, Adorno overlooks the communicative form of reason that provides a basis for consistent social critique that does not undermine itself. 
On my interpretation, Adorno's assessment of enlightenment and conceptual thought is less negative than Habermas maintains. Certainly, for Adorno, conceptual thought has always served the domination of nature. In that service, humanity has repeatedly criticised its own earlier forms of thought for being merely mythic or magical, therefore not providing the real knowledge that enables domination. In criticizing its earlier stages on these grounds, enlightened thought has repeatedly advanced the goals of freedom, reason, and knowledge - freedom from the distorting influence of natural impulses and from anthropomorphic projections; the ability to think rationally, free of such influences; knowledge of objects and the world as they really are. Thus: 'Every progress made by civilization has, along with domination, also renewed the prospect of its pacification', i.e. of the pacification of domination (DA 40/57). From its outset, enlightenment, and conceptual thought with it, have been ambiguous. Negatively, they have pursued domination; but positively, they have pursued criticism, reason, freedom, and knowledge.

So can Adorno criticize the negative side of enlightenment in light of its positive side? Perhaps not, for on Adorno's own account those positive values of reason, freedom, and knowledge have always been compromised, contaminated by the goal of domination with which they have been interwoven all along. However, that compromising affliction - the dialectic of enlightenment - could be removed if we pursued these enlightenment values in a new form that reconciled them with nature - reconciled in Adorno's not-fully-Hegelian sense. 'By virtue of this remembrance of nature in the subject, in whose fulfilment the unrecognized truth of all culture lies hidden, enlightenment is altogether opposed to domination' (DA 40/58), Adorno declares - thereby indicating both his ongoing commitment to enlightenment and his view that reconciliation with nature offers the solution to the 
problems of all culture so far. Were we to acknowledge our dependency on nature, then, we would realize that we can never totally control nature: we are of nature in the first place, so it is not rational to pursue such control. Indeed, such total control would - irrationally - entail total repression of our own instincts, although these motivate us to pursue control in the first place. The story of Odysseus and the sirens dramatises this. Odysseus can resist the sirens only by blocking off his senses, being chained, immobilised, to his ship's mast: he masters outer nature only by stifling his inner nature utterly. Admittedly, as natural beings, we cannot entirely escape our own urge to dominate nature. But this urge could be reconciled with the fact that total domination is irrational and undesirable if, recognizing that fact, we aimed to control nature only partially, not totally. Likewise we could gain greater freedom, critical capacity, and knowledge than we have attained hitherto if we admitted that these goals are only ever partially realizable, limited by a dependence on nature that we can never get around.

This conception of reconciliation as 'communication between the different', which (as we have seen) is shaped by Adorno's response to Hegel, permits Adorno to criticize enlightenment reason using enlightenment reason without invalidating his critique in the process. For he criticises enlightenment's historically existing and selfundermining, self-contradictory forms from the standpoint of an ideal, noncontradictory form of enlightenment reason that no society has yet realized - but that he can anticipate because the problems point forward to their solution. The fact that enlightenment has foundered throughout history because of its efforts to detach itself from nature indicates the needed solution: acknowledgement of our dependency on nature. Then enlightenment 'comes into its own only when it ... dares to sublate [aufzuheben] ... the principle of blind domination' (DA 42/59). That reconciled form 
of reason may criticize dialectical, historically existing reason because it corrects the problems with the latter. Equally, because reconciled reason is just the reconciled form of the same reason that is criticised - is nothing more than that same reason in reconciled form - the criticism is reason's self-criticism.

To say that the problems of enlightenment point forward to their solution is not to say that that solution must inevitably be realized - a model of inevitable historical progression that Adorno connects with Hegel. Against that model, Adorno firstly suggests that spirit would have to decide to acknowledge its hitherto dominating character and to reconcile itself with nature. Yet in much of his work Adorno doubts that twentieth-century humanity is capable of making that decision, so thoroughly have the machineries of modern bureaucracy and instrumental reason crushed our capacities for free decision-making. This seems to leave us at an impasse in which a decision is needed yet cannot be made. A more optimistic reading of Adorno is possible, though, in which he deliberately highlights, even exaggerates, negative tendencies within modernity in order to alert us to the threats that human freedom faces (for this reading see Cook, Adorno, Habermas, 172-4). On that reading, Adorno's position is not that our capacities for free choice have been altogether crushed but that they may yet become crushed if we do not heed the danger and act to avert it.

Second, again departing from Hegel's picture of historical progression, Adorno thinks that what is needed is for us to effect a decisive reorientation of history as it has unfolded so far: insofar as there has been a continuous history running from the slingshot to the megaton bomb, we need to break out of that entire course (ND 320/314). For Hegel, in contrast, historical progression has one single goal animating it throughout - the realisation of universal human freedom - so that each historical 
step forward is a step forward on the same course. But as Adorno sees it, to take another step forward on the same course that history has run so far would be to continue the effort of enlightenment to posit itself as separate from nature, which would merely incur another dialectical fall back into nature. Instead we need to reorientate enlightenment completely so that it is reconciled with nature. Even though this would be a complete reorientation, it is one towards which the dialectic of enlightenment points, as the solution that that dialectic necessarily requires. Once again, then, there remains a Hegelian element even to the way that Adorno departs from Hegel.

For Adorno, one single form of reason, subject-object reason, has propelled human history along its troubled course. Yet the dialectic to which this form of reason succumbs shows that reason must assume a reconciled form, from the standpoint of which reason can criticize its own hitherto defective forms and their oppressive societal expressions. Contrary to Habermas, social critique can be coherently grounded in subject-object reason because subject-object reason inherently has a dialectical structure that points it to develop beyond its so far problematic forms. This coherence in Adorno's approach to reason derives from the way in which he reshapes Hegelian dialectic, reconceiving the nature of the reconciliation that is the goal of the dialectical and historical process. In this reconception reconciliation is not the unity of reason and nature, but their co-existence in difference, a state in which human reason acknowledges that nature will always outstrip it.

\section{BIBLIOGRAPHY}

Adorno, Theodor. Negative Dialektik. Frankfurt: Suhrkamp, 1975. 
Adorno, Theodor. Dialektik der Aufklärung: Philosophische Fragmente. Edited by Rolf Tiedemann. Frankfurt: Suhrkamp, 1981.

Adorno, Theodor. 'Subject and Object'. In The Essential Frankfurt School Reader, ed. Andrew Arato and Eike Gebhardt, 497-511. New York: Continuum, 1982. Original German publication in 1969.

Adorno, Theodor. 'The Idea of Natural History'. Translated by Bob Hullot-Kentor. Telos 60 (1984): 111-124.

Adorno, Theodor. Negative Dialectics. Translated by E. B. Ashton. London: Routledge, 1990.

Adorno, Theodor, and Max Horkheimer. Dialectic of Enlightenment. Translated by John Cumming. London: Verso, 1997.

Adorno, Theodor. Hegel: Three Studies. Translated by Shierry Weber Nicholsen. Cambridge, Mass.: MIT Press, 1993. Original German publication in 1963. Adorno, Theodor. Minima Moralia. Translated by E. F. N. Jephcott. London: New Left Books, 1974. Original German publication in 1951.

Aristotle. Posterior Analytics. Second edn. Translated by Jonathan Barnes. Oxford: Clarendon, 1994.

Beiser, Frederick C. German Idealism, 1781-1801: The Struggle Against Subjectivism. Cambridge, Mass.: Harvard University Press, 2002.

Bernstein, J. M. 'Negative Dialectic as Fate: Adorno and Hegel'. In The Cambridge Companion to Adorno, edited by Tom Huhn, 19-50. Cambridge: Cambridge University Press, 2004.

Butler, Judith. Subjects of Desire: Hegelian Reflections in Twentieth-Century France. New York: Columbia University Press, 1987. 
Baumann, Charlotte. 'Adorno, Hegel and the Concrete Universal'. Philosophy and Social Criticism 37: 1 (2011), 73-94.

Cook, Deborah. Adorno, Habermas and the Search for a Rational Society. New York: Routledge, 2004.

Derrida, Jacques. Glas. Translated by John P. Leavey, Jr. and Richard Rand. Lincoln: University of Nebraska Press, 1986. Original French publication in 1974.

Finlayson, Gordon. 'Normativity and Metaphysics in Adorno and Hegel'. At www.sussex.ac.uk/Users/jgf21/research/NAM.rtf. Accessed 2/7/2013.

Forster, Michael. Hegel's Idea of a Phenomenology of Spirit. Chicago, IL: University of Chicago Press, 1998.

Habermas, Jürgen. The Philosophical Discourse of Modernity. Translated by Frederick Lawrence. Cambridge, UK: Polity Press, 1987. Orignal German publication in 1985 .

Hegel, G. W. F. Wissenschaft der Logik. 2 vols. Frankfurt: Suhrkamp, 1969.

Hegel, G. W. F. Enzyklopädie I: Die Wissenschaft der Logik. Frankfurt: Suhrkamp, 1970.

Hegel, G. W. F. Phänomenologie des Geistes. Frankfurt: Suhrkamp, 1970.

Hegel, G. W. F. Philosophy of Nature. 3 vols. Translated by M. J. Petry. London: Allen \& Unwin, 1970. Original German publication in 1817, revised edns 1827 , 1830.

Hegel, G. W. F. Hegel's Science of Logic. Translated by A. V. Miller. Atlantic Highlands, NJ: Humanities Press, 1969, paperback edn. 1989.

Hegel, G. W. F. Hegel's Phenomenology of Spirit. Translated by A. V. Miller. Oxford: Oxford University Press, 1977. 
Hegel, G. W. F. The Encyclopeadia Logic. Translated by T. F. Geraets, W. A.

Suchting and H. S. Harris. Indianapolis, IN: Hackett, 1991.

Irigaray, Luce. Speculum of the Other Woman. Translated by Gillian C. Gill. Ithaca:

Cornell University Press, 1985. Original French publication in 1974.

Macdonald, Iain. “"The Wounder will Heal”: Cognition and Reconciliation in Hegel and Adorno'. Philosophy Today 44 Suppl. (2000), 132-9.

Marx, Karl. Postface to the Second Edition of Capital: Volume One. Translated by Ben Fowkes. Harmondsworth: Penguin, 1976. Original publication in 1873.

Mueller, Gustav E. 'The Hegel Legend of "Thesis-Antithesis-Synthesis"'. In The Hegel Myths and Legends, edited by Jon Stewart, 301-5. Evanston, IL:

Northwestern University Press, 1996. Original publication in 1958.

Nietzsche, Friedrich. The Birth of Tragedy and Other Writings. Edited by Raymond Geuss and Ronald Speirs. Cambridge: Cambridge University Press, 1999. O'Connor, Brian. 'Adorno's Reconception of the Dialectic'. In A Companion to Hegel, edited by Stephen Houlgate and M. J. Baur. Oxford: Blackwell, 2011. Pinkard, Terry. Hegel's Idealism: The Explanation of Possibility. Philadelphia: Temple University Press, 1988.

Pippin, Robert B. Hegel's Idealism: The Satisfactions of Self-Consciousness. Cambridge: Cambridge University Press, 1989.

Stone, Alison. 'Adorno and the Disenchantment of Nature'. Philosophy and Social Criticism 32: 2 (2006), 231-53.

Wartenberg, Thomas E. 'Hegel's Idealism: the Logic of Conceptuality.' In The Cambridge Companion to Hegel, edited by Frederick C. Beiser. Cambridge: Cambridge University Press, 1993. 